\title{
Improper Service Assistances for Captial Investements in Rural Areas
}

\author{
Anudevi, V.Sailaja, S.Binapani
}

\begin{abstract}
Any economy's performance is measured in terms of macroeconomic parameter trends and patterns that include national income, consumption, savings, expenditure, and employment. This investigation gathers essential information from country families in Tamil Nadu It is discovered that none of the examination was led to gauge or break down the connection between Tamil Nadu rustic family unit salary, utilization, and venture, particularly at smaller scale level.
\end{abstract} service

Keywords : Food delivery apps, business methods, online

\section{INTRODUCTION}

The creating nations like India need assets for monetary improvement and development. For monetary advancement money the board is significant. While remembering liquidity and benefit are kept. The exhibition of any economy is estimated as far as the patterns and example of macroeconomic variable which incorporate national salary, utilization, sparing, venture and work. Per capita salary and utilization both are the proportion of Human advancement. Be that as it may, utilization is a more prominent pointer of human welfare. Utilization is a significant movement performed by the family unit part. Whatever individual pay we acquire, from one source or the other, is spent either on utilization or is spared. The present utilization is intensifying disparities [1].

While speculation is the absolute most factors for the improvement of an economy, it is reserve funds which gives the premise to venture. The range of speculation is in reality wide. A venture is tested with cluster of speculation openings like, bank stores and life coverage little sparing, business stores, bullions, land, corporate security securities, value, common assets and inclination shares[2].

In this straightforward condition, it is anything but difficult to see the connection between salary, utilization, and speculation. On the off chance that salary builds, at that point utilization and speculation will change. The result of salary is the most significant determinant of utilization. Be that as it may, for the equal explanation, when earnings decrease, utilization additionally falls all of a sudden, with decimating significances for human prosperity. The rustic family units

Revised Manuscript Received on December 11, 2019

Anudevi, Department of Science and Humanities, Bharath Institute of Higher Education and Research, Chennai , India. Email: Anudevi28@gmail.com

V.Sailaja, Department of Science and Humanities, Bharath Institute of Higher Education and Research, Chennai , India. Email: psaillajagmail.com

S.Binapani, Department of Science and Humanities, Bharath Institute of Higher Education and Research, Chennai, India. Email: bina.saravanangmail.com drive their salary from different sources like farming, compensation, domesticated animals, poultry and other independently employed exercises. Utilization use and family unit salary are two direct money related estimates used to assess the financial welfare of a populace. In any case, utilization consumption is alluded to pay as it pursues the long haul financial status of the family, especially in low pay nations. Different looks into are accessible identifying with the salary and utilization of family units.

There are bank stores as their significant inclination of speculation and salary impacts family speculator mindfulness in Pune city [9]. The majority of representatives have mindfulness about the modern protections and as salary increment mindfulness about protections likewise increments [3] [10]. There is dissimilarity in salary dissemination of various pay gatherings and destitution disparities in Sri Lanka [11]. At the point when the patterns and examples of nourishment utilization and dietary admission in provincial India analyzed between various states. The outcome indicated that month to month per capita utilization use, has recorded the most elevated [12].The salary age process in provincial sericulture uncovered the intensity of the winning procedure inside the country individuals. Pay from sericulture is affected endless supply of development, cost of crude silk, cost of reeling casing and send out profit amount [13].

\section{A. Objectives}

- To observe the association among Tamil Nadu's family income and rural expenditure.

- To research the association among Tamil Nadu's household income and rural investment.

To analyze the association between Tamil Nadu rural household income, consumption and investment.

\section{B. Techniques/Statistical investigation}

This examination depends on the essential information A poll is readied and the individual meetings strategy is utilized to gather the essential information from provincial family unit[14]. The example chose included 100 family units. Stratified arbitrary testing procedure is applied for test choice. Information gathered is examined by utilizing relapse examination and MANOVA.

\section{Discoveries}

The relapse result shows that there is a critical link between family pay and family unit utilization use. As the pay of the family unit increments, at the same time there is high increment in utilization use when contrasted with venture.

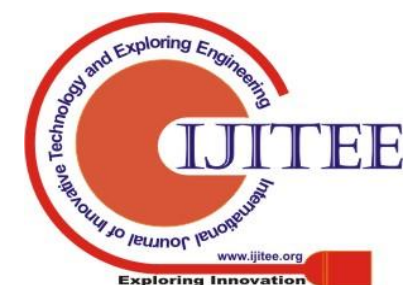


MANOVA results indicated that there is no critical connection among pay and utilization consumption, yet it is noteworthy in the event of complete venture.

\section{D.Application/Improvements}

None of the study was conducted in Tamil Nadu to quantify or evaluate the relationship between rural household income, consumption, and investment, primarily at micro-level[15]-[19]. Many studies of rural people's income, consumption, and investment habits are focused on secondary data that sometimes proves to be insufficient for the research. Most of the available data are not expected to serve Tamil Nadu's needs at ground level. The current research paper is therefore aimed at examining the relationship between rural Tamil Nadu's employment, consumption and investment.

\section{STSTEMENT OF PROBLEM}

Based on audit of writing it is discovered not any of the examination has been led to quantify or investigate connection between pay, utilization and venture of country family unit of Tamil Nadu particularly at miniaturized scale level. This is on the grounds that the NSSO and other identical associations or the official offices that gathers such information for the whole nation, doesn't by and large distribute information independently for country zones for the most part with regards to singular family units. A large portion of the examinations on pay, utilization and speculation example of country individuals depend on optional information which in some cases doesn't demonstrate to be satisfactory for the investigation[20]-[22]. The greater part of the information accessible doesn't serve the requirements of Tamil Nadu in a ground level planned. There exists a writing hole here.

\section{RESEARCH METHODOLOGY}

Primary data from rural households in Tamil Nadu were collected in this report. Questionnaire was designed to collect information from rural households using the system of personal interviews. For the collection of specimens, stratified random sampling is used.

\section{RESULT AND DISCUSSION}

\section{A. Income and consumption relation}

In basic relapse, we have just two factors, one variable (characterized as autonomous) is the base of the conduct of another (characterized as reliant variable). The central connection among pay and utilization is given Table 1 gives the estimation of $\mathrm{R}$ and $\mathrm{R} 2$ which shows high level of relationship $\mathrm{R}$ worth speaks to the straightforward connection and is $0.881[24]-[25]$. The $\mathrm{R} 2$ worth is 0.838 , which is exceptionally huge, subsequently demonstrates $83.8 \%$ of all out variety in subordinate variable that is yearly utilization consumption is portrayed by autonomous variable that is absolute salary of family. According to Table 2 estimation of $\mathrm{P}$ is 0.000 and in this way huge. Subsequently relapse model measurably surprisingly predicts the result variable. Table 3 demonstrates estimation of $\mathrm{P}$ is less than 0.05 and consequently noteworthy. Subsequently there is a huge connection between absolute utilization consumption and complete family unit pay of provincial Tamil Nadu. The utilization consumption can be foreseeing pay through after relapse condition: $\mathrm{Ce}=84669.804+0.205$ (pay).a

Table 1 - Model Summary

\begin{tabular}{|l|l|l|l|l|}
\hline Model & R & R Square & $\begin{array}{l}\text { Adjusted R } \\
\text { Square Std }\end{array}$ & Error of the Estimate \\
\hline .1 & $.881^{\mathrm{a}}$ & .838 & .749 & $\begin{array}{l}874.77 \\
9\end{array}$ \\
\hline
\end{tabular}

Table 2 - ANOVA Table

\begin{tabular}{|l|l|c|c|c|c|l|}
\hline \multicolumn{2}{|c|}{ Model } & \multicolumn{1}{c|}{$\begin{array}{c}\text { Sum of } \\
\text { Squares }\end{array}$} & df & $\begin{array}{c}\text { Mean } \\
\text { Square }\end{array}$ & F & Sig \\
\hline \multirow{2}{|c|}{$\begin{array}{l}\text { Regressio } \\
\mathrm{n}\end{array}$} & $4.903 \mathrm{E} 11$ & 1 & $4.903 \mathrm{E} 11$ & 49.947 & .000 \\
\cline { 2 - 7 } & & & & & \\
\hline
\end{tabular}

\section{B. Income and Investment Relation}

The R2 worth is 0.667 , which is enormous, consequently shows $66.7 \%$ of absolute variety in subordinate variable that is all out venture is depicted by free factor that is all out salary of family according to Table 5 estimation of $\mathrm{P}$ is 0.000 (which is under 0.05) and in this manner noteworthy. Thus relapse modular factually fundamentally predicts the result variable. There for Null theory is dismissed. Henceforth there is a huge connection among venture and pay of provincial family unit in Tamil Nadu. The venture can be anticipating salary through after relapse condition: $\mathrm{TI}=-31804.930+0.472$ (pay).

Table3 - Coefficientsa

\begin{tabular}{|l|l|l|l|l|l|l|}
\hline \multicolumn{2}{|l|}{ Model } & \multicolumn{2}{|l|}{$\begin{array}{l}\text { Unstandardized } \\
\text { Coefficients }\end{array}$} & $\begin{array}{l}\text { Standardize } \\
\text { d } \\
\text { Coefficients }\end{array}$ & T & sig \\
\cline { 2 - 5 } \multicolumn{2}{|l|}{} & B & Std.Enror & Beta & \\
\hline \multirow{2}{*}{1} & (Constant) & $\begin{array}{l}84669.8 \\
04\end{array}$ & 16826.393 & & 5.032 & .000 \\
\cline { 2 - 5 } & $\begin{array}{l}\text { TOTAL INCOME OF } \\
\text { FAMILY }\end{array}$ & .205 & .029 & .581 & 7.067 & .000 \\
\hline
\end{tabular}

\section{a. Dependent Variable: Annual Consumption Expenditure}

Table4 - Model Summary

\begin{tabular}{|l|l|l|l|l|}
\hline Model & R & R Squar & Adjusted R Square & Error of the Estimate \\
\hline .1 & $.709^{\mathrm{a}}$ & .667 & .605 & 808.119 \\
\hline
\end{tabular}

\section{b. Predictors: Total Income Of Family}

Table5 - ANOVAb Model

\begin{tabular}{|c|c|c|c|c|c|}
\hline Model & $\begin{array}{l}\text { Sum of } \\
\text { Squares }\end{array}$ & $\mathrm{df}$ & $\begin{array}{c}\text { Mean } \\
\text { Square }\end{array}$ & F & Sig \\
\hline \begin{tabular}{l|l}
1 & $\begin{array}{l}\text { Regressio } \\
\mathrm{n}\end{array}$
\end{tabular} & $2.128 \mathrm{E} 12$ & 1 & $2.128 \mathrm{E} 12$ & 13.439 & $.000^{\mathrm{a}}$ \\
\hline Residual & $1.061 \mathrm{E} 13$ & $\begin{array}{l}6 \\
7\end{array}$ & $1.583 \mathrm{E} 11$ & & \\
\hline Total & $1.273 \mathrm{E} 13$ & $\begin{array}{l}6 \\
8\end{array}$ & & & \\
\hline
\end{tabular}

c. Dependent Variable: Total Investment

Table6 - Coefficientsa

\begin{tabular}{|c|c|c|c|c|c|}
\hline \multirow[t]{2}{*}{ Model } & \multicolumn{2}{|c|}{$\begin{array}{l}\text { Unstandardized } \\
\text { Coefficients }\end{array}$} & \multirow{2}{*}{$\begin{array}{l}\text { Standardize } \\
\text { d } \\
\text { Coefficients } \\
\text { Beta }\end{array}$} & \multirow[t]{2}{*}{$\mathrm{T}$} & \multirow[t]{2}{*}{ sig } \\
\hline & B & Std.Error & & & \\
\hline \begin{tabular}{l|l} 
(Constant)
\end{tabular} & $\begin{array}{l}- \\
31804.93 \\
0\end{array}$ & 86377.458 & & -.368 & .714 \\
\hline $\begin{array}{l}\text { TOTAL INCOME } \\
\text { OF FAMILY }\end{array}$ & .472 & .129 & .409 & 3.666 & 00 \\
\hline
\end{tabular}




\section{Relationship between Income, Consumption and Investment of Rural}

This is under 0.001 demonstrating that there is noteworthy distinction between the co fluctuation lattices and subsequently suspicion of homogeneity is disregarded. This critical F shows that there no huge contrasts among the pay bunches on a straight association of two ward factors. Estimation of $\mathrm{n} 2$ demonstrates that $18 \%$ of multivariate difference of the needy factors is related with gathering factor. (Table 9)

Table 10 portrays the Leven's Test of correspondence of mistake difference test and its presumption of MANOVA and ANOVA that the fluctuations of every factor are indistinguishable over the gatherings Leven's Test isn't huge if there should arise an occurrence of utilization consumption as $\mathrm{P}>0.01$, however it is critical in the event of absolute speculation as estimation of $\mathrm{P}$ is 0.004 [23]. Consequently blunder fluctuation of utilization consumption is equivalent crosswise over gatherings while inconsistent if there should be an occurrence of all out venture.

According to Univariate ANOVA results, absolute venture and yearly utilization consumption subordinate factors are factually noteworthy. There are four degree of salary; there for numerous correlations are led to see which sets of means are extraordinary. To spare against type I mistake Bonferoni system is utilized.

Table7. Descriptive Statistics

\begin{tabular}{|c|c|c|c|c|c|}
\hline & \multicolumn{2}{|c|}{ Group wise income } & Mean & & $\mathrm{N}$ \\
\hline \multirow{5}{*}{$\begin{array}{l}\text { TOTAL } \\
\text { INVESTMENT }\end{array}$} & \multirow[t]{5}{*}{ dimension 1} & up to2 lakh & 129896.6316 & $2.21196 \mathrm{E} 5$ & 19 \\
\hline & & 2 lakh-3 lakh & 61971.4286 & $1.00904 \mathrm{E} 5$ & 14 \\
\hline & & 3 lakh -8 lakh & 181568.4211 & $3.87512 \mathrm{E} 5$ & 19 \\
\hline & & above 8 lakh & 541294.1176 & $6.49110 \mathrm{E} 5$ & 17 \\
\hline & & \begin{tabular}{|l|} 
Total \\
\end{tabular} & 231701.9710 & $4.32757 \mathrm{E} 5$ & 69 \\
\hline \multirow{5}{*}{$\begin{array}{l}\text { ANNUAL } \\
\text { CONSUMPTION } \\
\text { EXPENDITURE }\end{array}$} & \multirow[t]{5}{*}{ dimension 1} & up to2 lakh & 135852.6316 & 43163.09340 & 19 \\
\hline & & 2 lakh-3 lakh & 173297.1429 & 68710.90244 & 14 \\
\hline & & 3 lakh -8 lakh & 230134.7368 & $1.12480 \mathrm{E} 5$ & 19 \\
\hline & & above 8 lakh & 304560.0000 & $1.63489 \mathrm{E} 5$ & 17 \\
\hline & & \begin{tabular}{|l|} 
Total \\
\end{tabular} & 210977.3913 & $1.23268 \mathrm{E} 5$ & 69 \\
\hline
\end{tabular}

Table8. Box's Test of Equality of Covariance Matricesa

\begin{tabular}{|l|l|}
\hline Box's M & 73.628 \\
\hline F & 7.716 \\
\hline df1 & 9 \\
\hline df2 & 36984.280 \\
\hline Sig & .000 \\
\hline
\end{tabular}

Table 9 Multivariate Tests

\begin{tabular}{|c|c|c|c|c|c|c|c|}
\hline Effect & & Value & F & $\begin{array}{l}\text { Hypothesis } \\
\text { df }\end{array}$ & Error $\mathrm{df}$ & Sig. & $\begin{array}{l}\text { Partial } \\
\text { Eta } \\
\text { Squared }\end{array}$ \\
\hline \multirow[t]{4}{*}{ Intercept } & $\begin{array}{l}\text { Pillai's } \\
\text { Trace }\end{array}$ & .801 & $128.961^{\mathrm{a}}$ & 2.000 & 64.000 & .000 & .801 \\
\hline & $\begin{array}{l}\text { Wilks' } \\
\text { Lambda }\end{array}$ & .199 & $128.961^{\mathrm{a}}$ & 2.000 & 64.000 & .000 & .801 \\
\hline & $\begin{array}{l}\text { Hotelling's } \\
\text { Trace }\end{array}$ & 4.030 & $128.961^{\mathrm{a}}$ & 2.000 & 64.000 & .000 & .801 \\
\hline & $\begin{array}{l}\text { Roy's } \\
\text { Largest Root }\end{array}$ & 4.030 & $128.961^{\mathrm{a}}$ & 2.000 & 64.000 & .000 & .801 \\
\hline \multirow[t]{4}{*}{ Income } & $\begin{array}{l}\text { Pillai's } \\
\text { Trace }\end{array}$ & .351 & 4.614 & 6.000 & 130.000 & .000 & .176 \\
\hline & $\begin{array}{l}\text { Wilks' } \\
\text { Lambda }\end{array}$ & .662 & $4.890^{\mathrm{a}}$ & 6.000 & 128.000 & .000 & .186 \\
\hline & $\begin{array}{l}\text { Hotelling's } \\
\text { Trace }\end{array}$ & .491 & 5.160 & 6.000 & 126.000 & .000 & .197 \\
\hline & $\begin{array}{l}\text { Roy's } \\
\text { Largest Root }\end{array}$ & .448 & $9.699^{b}$ & 3.000 & 65.000 & .000 & .309 \\
\hline
\end{tabular}
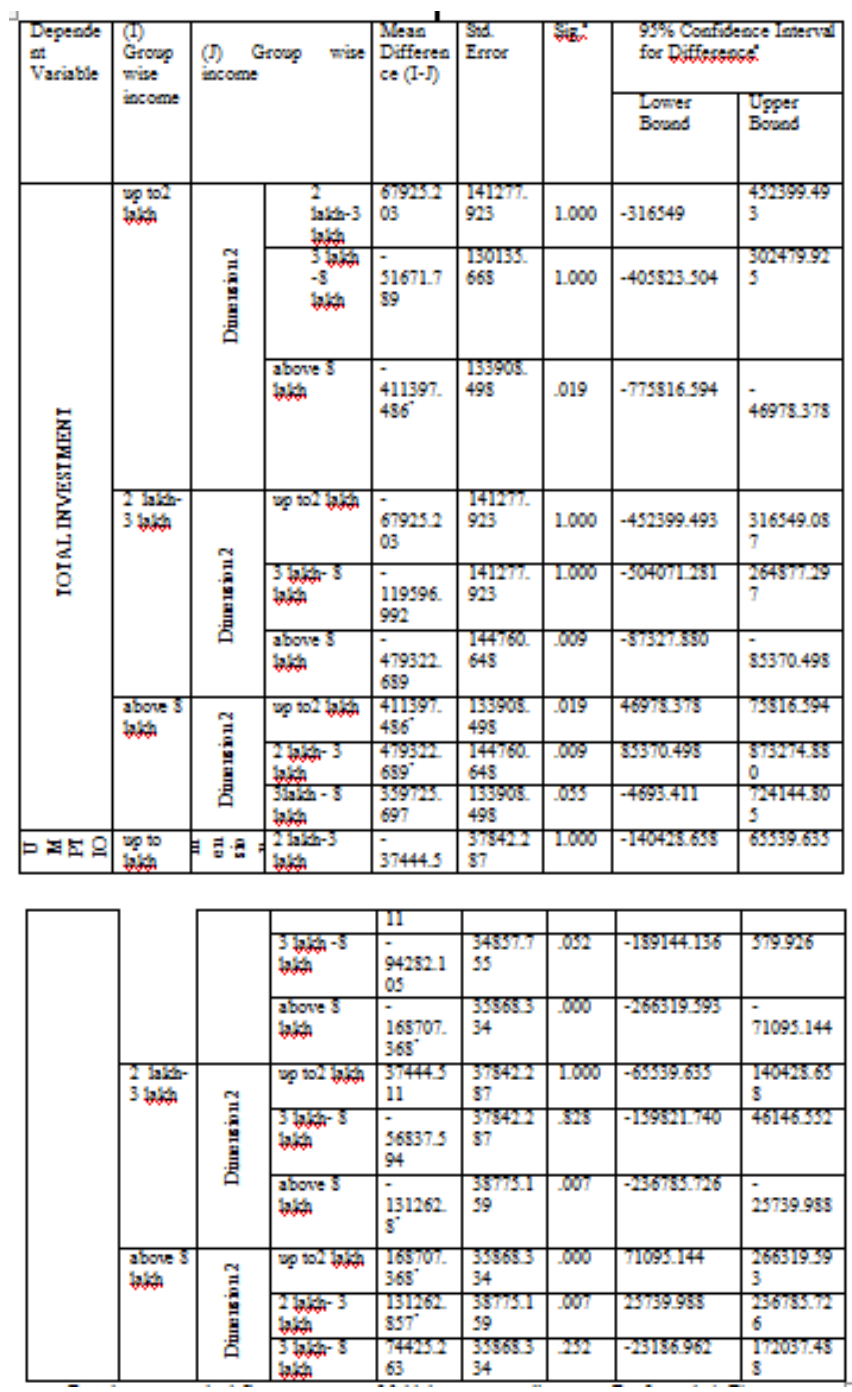

Table 10 - Pairwise Comparisons

Based on a marginal figure, a means. Multiple contrast adjustment: Bonferroni. *. The mean difference at the rate of 0.05 is important. (Sources: estimate of the researcher)

\section{CONCLUSION}

This investigation centers An Empirical Analysis of Relation between Income, Consumption and Investment of Rural Tamil Nadu. The primary target of this examination is to research the connection between salary, utilization and venture of provincial family unit in Tamil Nadu. The relapse result shows that there is a huge connection between family unit salary and family unit utilization use and there is additionally a huge connection between family unit pay and family unit interest in provincial Tamil Nadu. As the salary of the family unit increments, all the while there is high increment in utilization use when contrasted with venture. MANOVA results indicated that there is no critical connection among pay and utilization use, however it is noteworthy if there should arise an occurrence of complete speculation. 


\section{REFERENCES}

1. Vasanthi, S. \& Rabiyathul Basariya, S. 2019, "Influence of value analysis and cross training in industry", International Journal of Engineering and Advanced Technology, vol. 8, no. 6, pp. 1810-1811.

2. Velvizhi, R., Sri Gowtham, S. \& Jeya Priya, D. 2019, "Examination of early feedbacks for effective product retailing on E-commerce websites", International Journal of Engineering and Advanced Technology, vol. 8, no. 6 Special Issue 2, pp. 703-706.

3. Anuradha, C., Pothumani, S. \& Kavitha, R. 2019, "A novel method towards E-commerce", International Journal of Engineering and Advanced Technology, vol. 8, no. 6 Special Issue 2, pp. 535-538.

4. Thomas, J. \& Rabiyathul Basariya, S. 2019, "A study on the issues of financial ratio analysis", Indian Journal of Public Health Research and Development, vol. 10, no. 3, pp. 1079-1081.

5. Ramachandran, S. \& Rabiyathul Basariya, S. 2019, "Online marketing study on customer satisfaction and relationship", Indian Journal of Public Health Research and Development, vol. 10, no. 3, pp. 1072-1078.

6. Priya, R., Vinothini, G. \& Cor Jesu, C.D. 2019, "The mentor-protégé relationship for professional growth", Journal of Advanced Research in Dynamical and Control Systems, vol. 11, no. 9 Special Issue, pp. 1110-1119.

7. Jannifer Rani, N., Bina Pani, S. \& Nimisha, N.S. 2019, "A study on money back polices available in LIC", Journal of Advanced Research in Dynamical and Control Systems, vol. 11, no. 9 Special Issue, pp. 833-839.

8. Saillaja, V., Jhansi Rani, K. \& Catherine, R. 2019, "Global marketing management planning and organization", Journal of Advanced Research in Dynamical and Control Systems, vol. 11, no. 9 Special Issue, pp. 489-493.

9. Saillaja, V., Jhansi Rani, K. \& Catherine, R. 2019, "The new phase of marketing information system", Journal of Advanced Research in Dynamical and Control Systems, vol. 11, no. 9 Special Issue, pp. 482-488.

10. Thoufiqulla \& Raju, D.V. 2019, "Perception of indian investor towards investment in mutual funds with special reference to mip funds", Journal of Advanced Research in Dynamical and Control Systems, vol. 11, no. 5, pp. 177-183.

11. Jasmine, K.R.M. \& Basariya, S.R. 2018, "A study on the customers benefits on mutual funds", International Journal of Civil Engineering and Technology, vol. 9, no. 4, pp. 45-48.

12. Vasanthi, S. \& Basariya, S.R. 2019, "Pros and cons of on the job training versus off the job training", International Journal of Scientific and Technology Research, vol. 8, no. 10, pp. 671-674.

13. Pavithra, J. \& Ganesan, M. 2016, "A study on awareness and impact of micro-financial schemes", International Journal of Applied Business and Economic Research, vol. 14, no. 8, pp. 5449-5460.

14. Pavithra, J., Dilli Babu, P. \& Ambuli, T.V. 2014, "A study on budgetary control at Maruti Service Masters, Chennai", International Journal of Applied Business and Economic Research, vol. 12, no. 2, pp. 151-161.

15. Gunaraja, T.M. \& Venkatrama Raju, D. 2018, "Determining factors of organisational climate with reference to leadership styles", International Journal of Mechanical Engineering and Technology, vol. 9, no. 9, pp. 1327-1332.

16. Gunaraja, T.M. \& Venkatrama Raju, D. 2018, "The role of job satisfaction and training of employees in determining organisational climate of a selected industry", International Journal of Civil Engineering and Technology, vol. 9, no. 8, pp. 1266-1269.

17. Aarathy, T.S. \& Raju, D.V. 2018, "Performance appraisal and its effects on employees with respect to it sector in Chennai city", International Journal of Civil Engineering and Technology, vol. 9, no. 6, pp. 1535-1538.

18. Aarathy, T.S. \& Raju, D.V. 2018, "Employee perception towards performance appraisal system in IT sector", International Journal of Mechanical Engineering and Technology, vol. 9, no. 5, pp. 131-135.

19. Porselvi, W., Jublee, D. \& Sivanesan, G. 2018, "A study on factors influencing adoption of technology and innovation in banking industry, tamilnadu, India", International Journal of Mechanical Engineering and Technology, vol. 9, no. 5, pp. 789-800.

20. Akessa, G.M. and Dhufera, A.G., 2015. Factors That Influences Students Academic Performance: A Case of Rift Valley University, Jimma, Ethiopia. Journal of Education and Practice, 6(22), pp.55-63.

21. Miller, G. and Shih, C.C., 1999. A faculty assessment of the academic rigor of on-and off-campus courses in agriculture. Journal of Agricultural Education, 40, pp.57-65.

22. Tsinidou, M., Gerogiannis, V. and Fitsilis, P., 2010. Evaluation of the factors that determine quality in higher education: an empirical study. Quality Assurance in education, 18(3), pp.227-244.

23. Farooq, M.S., Chaudhry, A.H., Shafiq, M. and Berhanu, G., 2011. Factors affecting students' quality of academic performance: a case of secondary school level. Journal of quality and technology management, 7(2), pp.1-14.

24. Fitsilis, P., Gerogiannis, V. and Anthopoulos, L., 2014. Ontologies for software project management: a review. Journal of Software Engineering and Applications, 7(13), p.1096.

25. Adams, J.D. and Jaffe, A.B., 1996. Bounding the effects of R\&D: an investigation using matched establishment-firm data(No. w5544). National bureau of economic research.

\section{AUTHORS PROFILE}

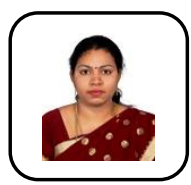

Anudevi Assistant Professor, Department of Science and Humanities, Bharath Institute of Higher Education and Research, Chennai, India.

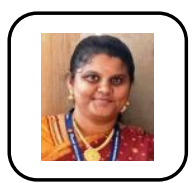

V.Sailaja Assistant Professor, Department of Science and Humanities, Bharath Institute of Higher Education and Research, Chennai, India.

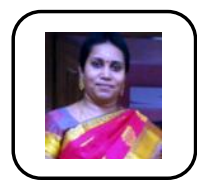

S.Binapani Assistant Professor, Department of Science and Humanities, Bharath Institute of Higher Education and Research, Chennai, India. 